\title{
EVALUATING FARM IRRIGATION WATER MANAGEMENT MODELS FOR WHEAT AND CORN CROPS
}

\section{Abd El Fattah.N. G' ${ }^{1}$, M. M.Ibrahim ${ }^{2}$ and M.H.Ramadan ${ }^{3}$}

\begin{abstract}
The CROPWAT, CAMISM and IRRIS scheduler irrigation water management models were compared, tested and evaluated under Egyptian conditions. The comparison parameters were ETo, irrigation water quantities and yield reduction to different levels of water stress. Wheat and corn crops were selected for examination. The results showed that there is a highly significant difference among tested models on Eto values, irrigation water quantities and the yield reduction percentage to different water stress levels for the chosen crops. IRRIS model recorded lower values of all parameters. Coming in ascending order the CAMISM then CROPWAT. CROPWAT and CAMISM model are more realistic in values of irrigation requirements than IRRIS model as both models depend on actual solar hours to account solar radiation contrariwise IRRIS accounts for max, min temperature to calculate solar radiation. CROPWAT is the only model among tested models has the availability to calculate the deficit irrigation in relation to crop yield through many options.
\end{abstract}

Keywords: Models, Irrigation Management, Irrigation Scheduling, Deficit Irrigation, Water Balance, Yield response to water.

\section{INTRODUCTION}

7 me main issue concerning the on farm irrigation water management is when to irrigate andhow much water to apply. 1 Water conservation and demand management principles in the agricultural sector cannot be applied without accurate and reliable method of crop water requirement determination so the irrigator needs to know the daily crop water use of each crop, measure rainfall and the amount of water applied.(Woyessa et al., 2004).

${ }^{1}$ Demonstrator, Agric. Eng. Dept., Faculty of Agric., Al-Mansoura Univ.

${ }^{2}$ and ${ }^{3}$ Assist. Prof. and Prof. of Agric. Eng., Faculty of Agric., Al-Mansoura Univ. 
The fundamental goal of deficit irrigation is to increase water use efficiency, either by reducing irrigation adequacy or by eliminating the least productive irrigations (Hillel, 1972; Barrett and Skogerboe, 1980).

High-yielding varieties crops are more sensitive to water stress than lowyielding varieties; for example, deficit irrigation had a more adverse effect on the yields of new maize varieties than on those of traditional varieties (FAO, 1979). Crop varieties that are most suitable for deficit irrigation arethose with a short growing season and are tolerant of drought (Stewart and Musick, 1982).

The monthly ETo resultsof the Mehran model (Laghari,2009), were compared with CROPWAT model. There was insignificant difference between the both models. The CROPWAT model needs additional data of Humidity \& SolarRadiation as compared to the Mehran Model. The Mehran Model takes wind speed in $\mathrm{m} / \mathrm{secas}$ directly mentioned in Penman Monteith.

CROPWAT was designed as a practical tool to carry out standard calculations for design and management of irrigation schemes, and for improving irrigation practices. The CROPWAT model has become the international standard and used on worldwide scale for irrigation management, however it still needs verification in different locations.(Van Heerden et al., 2001).

A relatively simple and easy-to-use irrigation scheduling program, KanSched, was developed and tested to schedule irrigations using daily inputs of reference evapotranspiration (grass, ETo; or alfalfa, ETr), rainfall, and irrigation to maintain and chart a field water balance (Clark et al., 2002). KanSched was easy-to-use, had nice displays, and was relatively versatile for use in States other than Kansas (Henggeler, 2002)

The main objective of this study is to evaluate CROPWAT, CAMISM and IRRIS scheduler models for irrigation water management under the Egyptian conditions.Moreover, establish comparisons among different tested models with regard to ETo, irrigation water quantities of different 
crops in different soil types and irrigation scheduling to determine the best model.

\section{METHODOLOGY}

\section{Study area}

The study site is the Dakahlia governorate which located in North of delta, Egypt. It covers an area of approximately $3500 \mathrm{~km}^{2}$. It represents about $7 \%$ of Egypt population, in less than $0.35 \%$ of Egypt land, which bring about great pressure on water demand with the current economic development and the waste of water in agriculture, Its climate is characterized by hot summer and cold-dry winter. The mean annual temperature is $26.8^{\circ} \mathrm{C}$ and the annual average rainfall reaches $26.7 \mathrm{~mm}$.

\section{Weather data (parameters) and source}

The weather data used in this study are mainly daily based meteorological data including maximum temperature, minimum temperature, maximum humidity, minimum humidity, average humidity, Sunshine hour, wind speed and rainfall for years 2012 and 2013.These data were gathered from the automatic weather stationin the Department of Agricultural Engineering type (Vantage Pro2, Davis, USA) which located at $31.0437^{\circ} \mathrm{N}, 31.352^{\circ} \mathrm{E}$ and $6.73 \mathrm{~m}$ altitude.

\section{Data collection}

\section{Crop and soil}

\section{Crop data}

The chosen crops have a big portion in total irrigated area of the study area that includes Wheat, Bean and Egyptian Clover (winter crops) and Corn, Tomato and Potato (summer crops). The crop data are based on FAO(1998). The crops parameters are planting date, Harvest date, maximum root depth $(\mathrm{m})$, crop coefficients $\left(\mathrm{K}_{\mathrm{c}}\right)$, Growth stage (days), critical depletion fraction, yield response factor $\left(\mathrm{K}_{\mathrm{y}}\right)$, crop height $(\mathrm{m})$, and Electrical conductivity of irrigation water $\left(\mathrm{EC}_{\mathrm{w}}\right)$, Electrical conductivity of the soil saturation (ECe ) and Maximum tolerable electrical of the soil saturation (Max ECe) values that is required to run the models . 


\section{Soil data}

The soil types found at the study area are heavy to medium class. These soiltypes have total available water holding capacity of approximately $192 \mathrm{~mm} / \mathrm{m}$ and $167 \mathrm{~mm} / \mathrm{m}$ respectively (Keller and Bliesner, 1990). Maximum rain infiltration rate is $30 \mathrm{~mm} /$ day and the Readily Available Water (RAW) is 50 and $90 \mathrm{~mm} / \mathrm{m}$ respectively. All these parameters in addition to initial soil moisture depletion (percentage of TAM) are entered to the models to make irrigation scheduling after selecting the crop type and its properties.

\section{Irrigation practices}

Mainly surface irrigation system ( $\sim 50 \%$ efficiency) is used. The practice most likely used is to refill soil to field capacity. However, deficit irrigation strategy in relation to yield response was considered in this study. The deficit range was $5 \%$ to $30 \%$ and $5 \%$ to $20 \%$ for Wheat and Corn respectively. An increment of $5 \%$ was applied in that range.

\section{Scheduling criteria}

The selected scheduling criteria for the CROPWAT model were:

1) Irrigation timing (irrigate at $100 \%$ Critical depletion).

2) The irrigation application depth (refill soil to field capacity).

3) Irrigation system efficiency.

\section{Tested models}

Figure (1) shows the flow chart describing the comparison criteria among the tested models, the following steps demonstrate the differences among the tested model sused to manage irrigation scheduling.

\section{CROPWAT 8.0}

\section{Description}

CROPWAT 8.0 is a computer program for irrigation planning and management, developed by Smith (1992). Its basic functions are calculation of ETo, Crop Water Requirements (CWR), and scheduling irrigations. The model uses the modified FAO Penman-Monteith method for calculating (Monthly - Decade - Daily) ETo. 


\section{Input data}

\section{Climate}

The equation used for computing solar radiation in CROPWAT is given by FAO (1998) as follows:

$$
\mathrm{R}_{\mathrm{s}}=\left[\mathrm{a}_{\mathrm{s}}+\mathrm{b}_{\mathrm{s}} \frac{\mathrm{n}}{\mathrm{N}}\right] \mathrm{R}_{\mathrm{a}}
$$

Where $\mathrm{Ra}$ is the extraterrestrial radiation expressed in equivalent evaporation in $\mathrm{mm} /$ day, $\mathrm{n}$ is the mean day light hours, and $\mathrm{N}$ is maximum possible duration of sunshine or day light hours.

\section{Effective Rainfall}

Only a part of the rainfall can be effectively used by the crop, depending on its root zone depth and the soil storage capacity. Different methodsexist to estimate the effective rainfall in this model (FAO, 1992) and the selected method is the USDA soil conservation service as follows:

For $\mathrm{P} \leq 250 / 3 \mathrm{~mm}$

$$
\begin{aligned}
& P_{\text {eff }}=[P \times(125-0.2 \times 3 \times P)] \\
& P_{\text {eff }}=(125 / 3+0.1 \times \mathrm{P})
\end{aligned}
$$$$
\text { For } \mathrm{P}>250 / 3 \mathrm{~mm}
$$

Where: $p_{\text {eff }}$ is the precipitation rate.

\section{Crop and Soil Data}

The parameters for crop and soil mentioned previously are the same ones used to calculate the crop water requirements (CWR).

\section{Scheduling option}

CROPWAT model have many options regarding to the scheduling criteria which include the irrigation timing, application depth and irrigation system efficiencyat critical depletion, refill soil to field capacity and 50\% of these options selected from the model and used for completing the irrigation scheduling.

\section{Leaching requirements (LR)}

Defined as the excess amount of water which applied during the irrigation for the purpose of leaching. CROPWAT model added the accounted amount for the leaching requirements to the net irrigation water 
requirements (NIWR) as the following equation according to Savva and Frenken (2002).

$$
\mathrm{NIWR}_{=} \mathrm{ET}_{\mathrm{C}}-\mathrm{Pe}+\mathrm{LR}
$$

Where ETc is crop evapotranspiration ( $\mathrm{mm} /$ day), and Pe is effective rainfall $(\mathrm{mm})$.

\section{CAMISM}

\section{Description}

CAMISM (Computer-Aided Mapping Irrigation Scheduling) is a friendly user computer program determines the exact time and the exact amount of water to apply to the field developed by Ramadan et al. (2006).The model uses four methods for calculating the ETo; Blanny-Criddle, Solar radiation, Modified FAO Penman-Monteith and Pan Evaporation based on daily basis - (first, second and third) ten days period and monthly basis. The parameters and equations used for climate, soil and crop used on the CAMISM are the same parameters used by CROPWAT model. The method used for calculating the Pe on CAMISM that used with CROPWAT.The CAMISM considers the Pe as the portion of deciduous precipitation that can effectively used by plants.The CAMISM system in determining the irrigation time is to irrigate when accumulated deficit equal to or exceed the management allowable depletion(MAD). CAMISM model skips the window of LR if rainfall exceeds ETc.The vice versa is to use the $\mathrm{EC}_{\mathrm{w}}, \mathrm{EC}$ and Max ECe input text boxes to add that amount accounted for leaching requirements.

\section{IRRIS scheduler}

\section{Description}

IRRIS model is acomputer program estimates soil moisture, available nitrogen to assist with irrigation scheduling and nitrogen application decision developed by Joern and Hess (1997). The model uses Modified FAO Penman-Monteith for calculating ETo. There is no difference among the parameters used in this model and other models for calculating the crop water requirements (CWR), irrigation scheduling and LR.But 
IRRIS differs from CROPWAT and CAMISM for calculating the solar radiation as givenby equation (5):

$$
\mathrm{R}_{\mathrm{s}}=\mathrm{K}_{\mathrm{Rs}} \sqrt{\left(\mathrm{T}_{\max }-\mathrm{T}_{\min }\right)} \mathrm{R}_{\mathrm{a}}
$$

Where $\mathrm{T}_{\max }$ and $\mathrm{T}_{\min }$ are the maximum and minimum temperature respectively and $\mathrm{K}_{\mathrm{Rs}}$ is the adjustment coefficient $(0.16-0.19)\left[{ }^{\circ} \mathrm{C}^{-0.5}\right]$.

\section{Comparison parameters among models}

\section{Reference evapotranspiration (ETo)}

The used equation for calculating ETo in the tested models is the modified FAO Penman-Monteith method. According to (Allen et al., 1998) as follows:

$$
\text { ETo }=\frac{0.408 \Delta\left(R_{n}-G\right)+\gamma \frac{900}{T+273} u_{2}(e s-e a)}{\Delta+\gamma\left(1+0.34 u_{2}\right)}
$$

Where, $R_{n}=$ net radiation at the crop surface $\left(M J / \mathrm{m}^{2}\right.$.day), $G=$ soil heat flux density $\left(\mathrm{MJ} / \mathrm{m}^{2}\right.$.day $), \mathrm{T}=$ mean daily air temperature at $2 \mathrm{~m}$ height $\left({ }^{\circ} \mathrm{C}\right), \mathrm{u}_{2}=$ wind speed at $2 \mathrm{~m}$ height $(\mathrm{m} / \mathrm{sec})$, es-ea = saturation vapour pressure deficit $(\mathrm{Kpa}), \Delta=$ slope vapour pressure curve $\left(\mathrm{Kpa} /{ }^{\circ} \mathrm{C}\right)$, and $\gamma=$ psychrometric constant $\left(\mathrm{Kpa} /{ }^{\circ} \mathrm{C}\right)$.

\section{Net irrigation water requirements (NIWR)}

Refers to the water that must be supplied through the irrigation system to ensure that the crop receives its full crop water requirements and there is no difference concerning the calculation method of this point for the three tested models.

\section{Gross irrigation water requirements (GIR)}

In CAMISM model, GIR are calculated by the following equation:

$$
G I R=\frac{D_{i}}{1-\mathrm{LR}} \times(1+W a)
$$

Where $\mathrm{Wa}=$ percentage of water added to each irrigation run, $\mathrm{Di}=$ soil water depletion in $\mathrm{mm}$ on day i. In CROPWAT and IRRIS, GIR are calculated by the following equation: 


$$
d=\mathrm{d}_{n} / \frac{E_{a}}{100}
$$

Where $d=$ gross depth per irrigation application, $m m, d_{n}=$ net depth of water application per irrigation, to meet consumptive use requirements, $\mathrm{mm}$, and $\mathrm{E}_{\mathrm{a}}$ is the application efficiency.

\section{Irrigation scheduling}

Irrigation scheduling was based on the depletion percentage of the total available water on current root depth position, computed by the models on daily basis by using equation of water balance according to Smajstrlaet al. (2006):

$$
\Delta \mathrm{S}=\mathrm{R}+\mathrm{I}-\mathrm{ET}-(\mathrm{D}+\mathrm{Ro})
$$

Where, $\Delta \mathrm{S}$ is the change in soil water storage, $\mathrm{R}=$ rainfall measured at the field site, I is irrigation applied, ET isestimated evapotranspiration, and D + Ro drainage and runoff, calculated as rainfall in excess of that which can be stored in the soil profile to field capacity.

\section{Deficit irrigation strategy in relation to crop yield.}

CROPWAT is the only model which used for calculating water deficit at different levels, by selecting the option (irrigate below or above critical depletion), from the irrigation timing window and the yield reduction percentages for different crops at different levels of deficit. The following equation is used tocalculate the yield reduction according to FAO (1986).

$$
\left[1-\frac{Y_{a}}{Y_{m}}\right]=K_{y} \times\left[1-\frac{E T_{a d j}}{E T_{c}}\right]
$$

Where $Y_{a}$ and $Y_{m}$ actual and maximum yields of the crop respectively $[\mathrm{kg} / \mathrm{ha}], \mathrm{Ky}=$ yield response factor and $\mathrm{ETc}_{\mathrm{adj}}=$ actual (adjusted) crop evapotranspiration as a result of environmental or water stresses.

\section{Statistical analysis}

The Statistical Analysis System (SAS) (2011) used for correlation, linear regression and RMSE. Correlation coefficient analysis used to determine the degree of association between CAMISM, IRRIS and best-fit line. The equation used for linear regression is $\mathrm{y}=\mathrm{a}+\mathrm{b} \times$, where $\mathrm{y}$ represents ETo calculated by (CAMISM and IRRIS) models, $\times$ is the CROPWAT model, 
$\mathrm{a}$ and $\mathrm{b}$ are constant representing the intercept and slope of the regression equation respectively. The root mean square error (RMSE) used to test which model performed best.

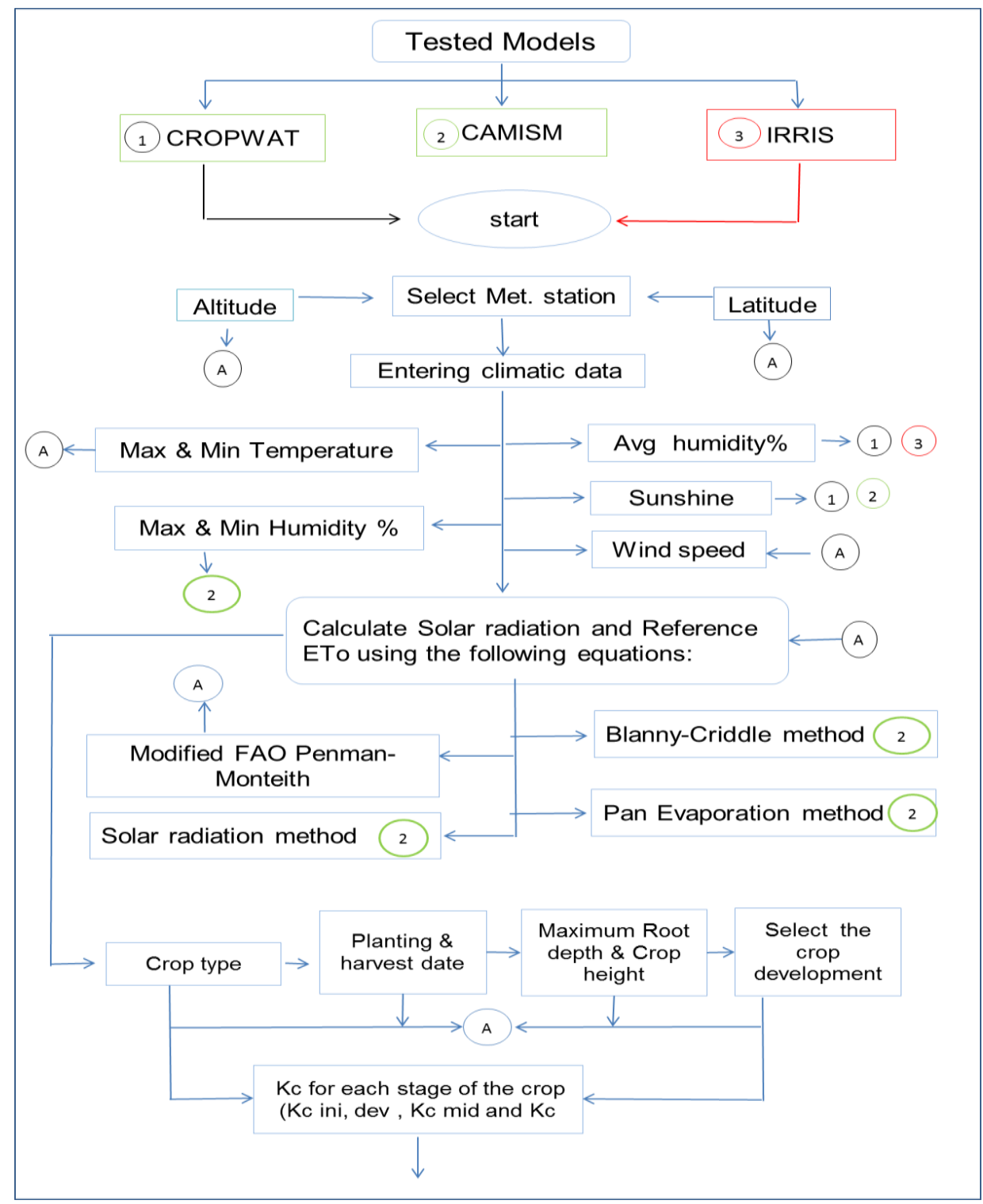

Figure (1): Flow chart describing the comparison criteria among the tested models.

$\mathrm{A}=$ refers to data required by the three tested models.

$1=$ required by CROPWAT model.

$2=$ required by CAMISM.

$3=$ required by IRRIS. 


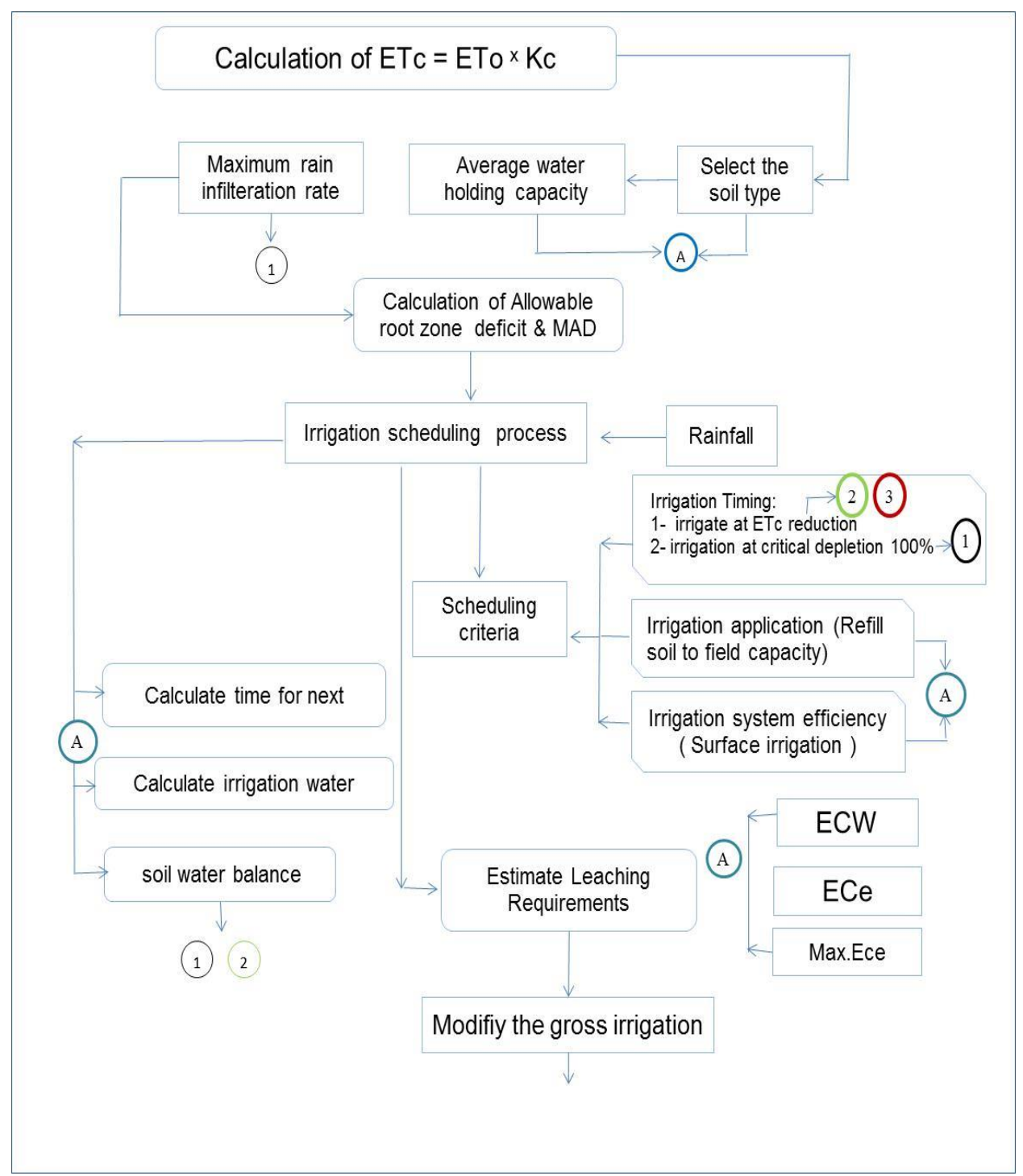

Figure (1):Continued.

\section{RESULTS AND DISCUSSION}

\section{Reference evapotranspiration (ETo)}

The correlation results among the tested models for Wheat ETo using penman-monteith method as given in Figure (2) show the linear regression analysis for CAMISM and IRRIS models to test the accuracy of its results by the extent of their proximity to the "best-fit"line. The 
gradientof CAMISM lineis 0.98 (closer to 1), while the gradient of IRRIS line is 0.88 which indicates that CAMISM model has high prediction than IRRIS.The coefficient of determination for the linear correlation of CAMISM, $\mathrm{R}_{1}{ }^{2}=0.99$, while the coefficient of determination for IRRIS is $\mathrm{R}_{2}{ }^{2}=0.98$. On the other hand the calculated $\mathrm{F}$ value $=5.71$ in Table (2) is highly significant at $1 \%$ level. According to the analysis of varianceas shown in Figure (2) the Standard Error (SE) value for CAMISM ranges from \pm 0.00861 to \pm 0.0287 , whereas it ranges from \pm 0.0113 to \pm 0.0376 for IRRIS model.From the analysis of deviation the STDEV for CAMISM from "best-fit" line $=0.0253$, whereas the STDEV for IRRIS from "best-fit" line $=0.1574$ as shown in Figure (2) that means CAMISM has reliability of the linear relationship with CROPWAT than IRRIS model.

Figure (3) shows the gradient of CAMISM model for Corn is 1.0118, while the gradient of IRRIS is 0.78 . The coefficient of determination for the linear correlation of CAMISM, $\mathrm{R}_{1}{ }^{2}=0.97$, while $\mathrm{R}_{2}{ }^{2}=0.79$ for IRRIS. The calculated $\mathrm{F}$ value $=184.47$ in Table (3) is highly significant at $1 \%$ level that means CAMISM model hold good linearity than IRRIS. SE for CAMISM ranges from \pm 0.0173 to \pm 0.0107 , whereas it ranges from \pm 0.036 to \pm 0.223 for IRRIS model as given in Figure (3). STDEV of CAMISM model from the "best-fit" line is $=0.0082$, whereas of IRRIS is 0.1556 as shown in Table (1).

It may be noticed that deviation from 1:1 for Corn is bigger than that for Wheat crop. This could be explained that equation (1) accounts for actual solar hours where equation (2) accounts for max andmin temperature for calculating solar radiation.

Table (1): Analysis of deviationfor the tested models from the "best fit "line (1:1) for different crops.

\begin{tabular}{|c|c|c|}
\hline \multirow{2}{*}{ Crop type } & CAMISM & IRRIS \\
\cline { 2 - 3 } & S.D from (1:1) & S.D from (1:1) \\
\hline Wheat & 0.0253 & 0.1574 \\
\hline Com & 0.0082 & 0.1556 \\
\hline
\end{tabular}




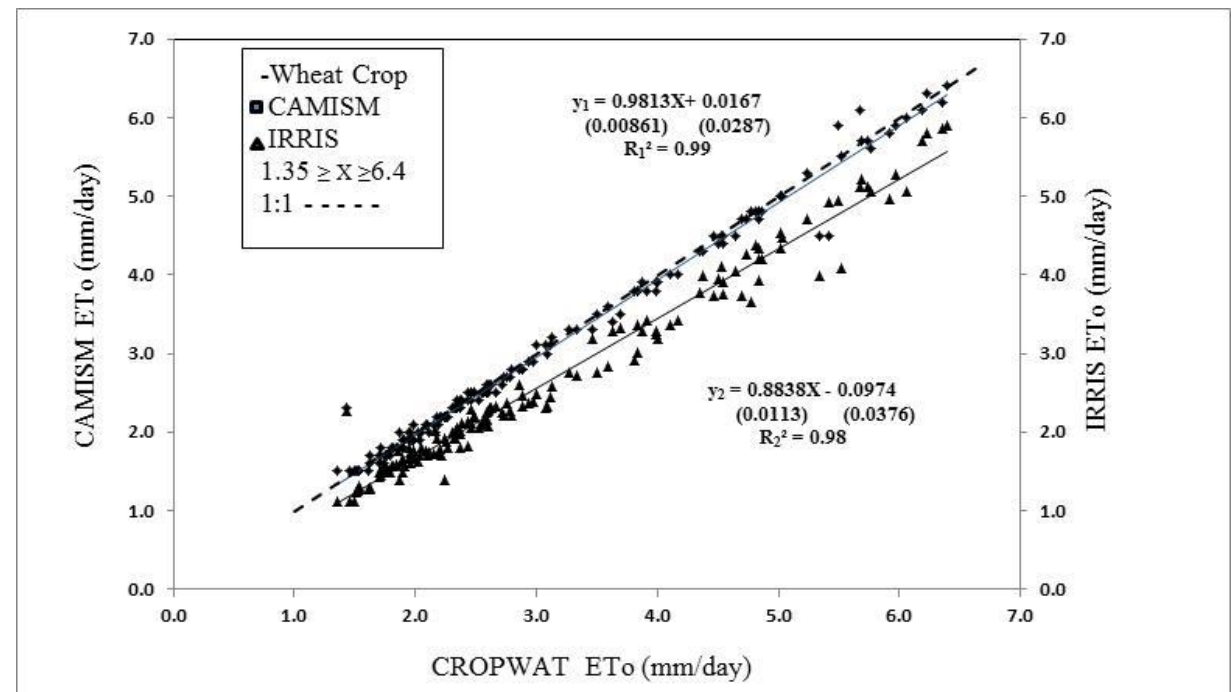

Figure (2): The correlation among CROPWAT, CAMISM, and IRRIS models; ET $_{0}$ for Wheat crop.

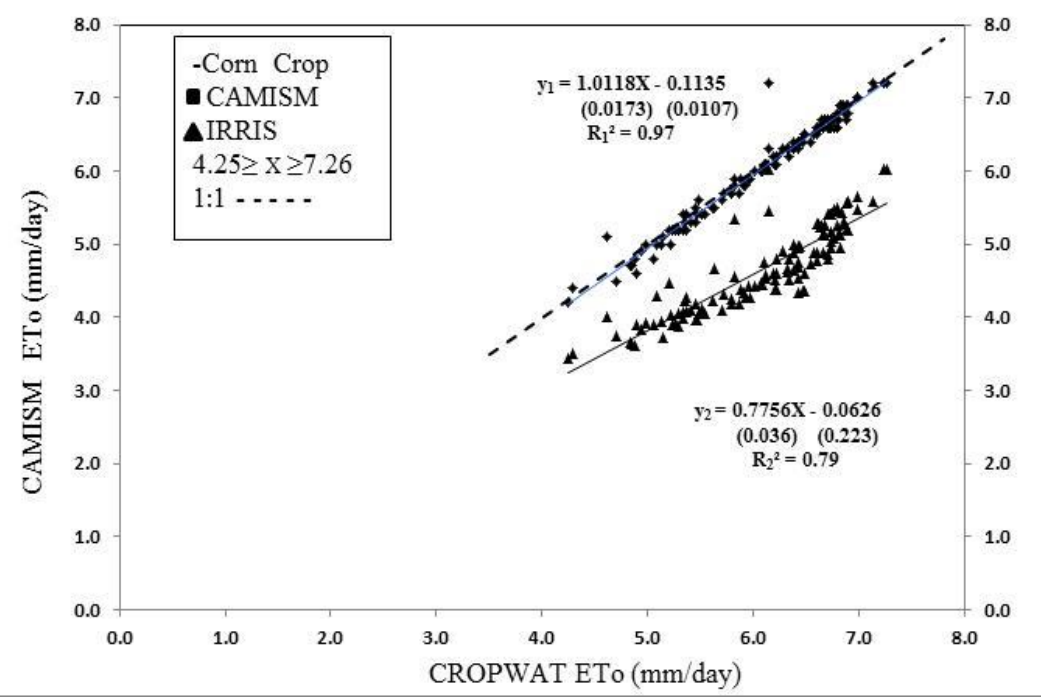

Figure (3): The correlation among CROPWAT, CAMISM, and IRRIS models; ET for Corn crop.

Table (2):Analysis of variance for the relationship among the tested models on ETo values forWheat crop.

\begin{tabular}{|c|c|c|c|c|c|}
\hline S.V & DF & S.S. & M.S. & F value & significance \\
\hline Treat & 2 & 19.375 & 9.687 & 5.71 & $* *$ \\
\hline Error & 462 & 783.76 & 1.696 & & \\
\hline Total & 464 & 803.133 & & & \\
\hline
\end{tabular}


Table (3):Analysis of variance for the relationship among the tested models on ETo values for Corn crop.

\begin{tabular}{|c|c|c|c|c|c|}
\hline S.V & DF & S.S. & M.S. & F value & significance \\
\hline Treat & 2 & 166.81 & 83.4 & 184.47 & $* *$ \\
\hline Error & 372 & 168.19 & 0.452 & & \\
\hline Total & 374 & 334.99 & & & \\
\hline
\end{tabular}

Table (4): Means, SD and L.S.D from the analysis of variance in the tested models for Wheat and Corn crops.

\begin{tabular}{|c|c|c|c|c|}
\hline \multirow{2}{*}{ Tested Models } & \multicolumn{2}{|c|}{ Wheat } & \multicolumn{2}{c|}{ Corn } \\
\cline { 2 - 5 } & Mean & S.D & Mean & S.D \\
\hline CROPWAT & $3.0489^{\mathrm{a}}$ & 1.354 & $6.115^{\mathrm{a}}$ & 0.693 \\
CAMISM & $3.008^{\mathrm{a}}$ & 1.337 & $6.074^{\mathrm{a}}$ & 0.714 \\
IRRIS & $2.597^{\mathrm{b}}$ & 1.212 & $4.679^{\mathrm{b}}$ & 0.605 \\
\hline L.S.D $_{0.05}$ & \multicolumn{2}{|c|}{0.2907} & \multicolumn{2}{c|}{0.1672} \\
\hline
\end{tabular}

$\mathrm{a}-\mathrm{b}=$ Means with the same letter in each column are not significantly at $\mathrm{P} \leq 0.05$

\section{Net irrigation water requirements (NIWR)}

Wheat life cycle can be divided into four growth stages each stage has its own duration and its own NIWR which differs among tested models till the fasting date of the crop as shown in Figure (4). The results in Table (5) reveals that seasonal NIWR for Wheat crop in tested models are 295.2, 284.7, and $296.4 \mathrm{~mm} / \mathrm{season}$ on heavy soil for CROPWAT, CAMISM and IRRIS respectively, meanwhile on medium soil are 305.9, 330 , and $288.5 \mathrm{~mm} / \mathrm{season}$. Where the amounts of NIWR over the period from $1^{\text {st }}$ to $21^{\text {st }}$ day differ among the models as CROPWAT and CAMISM has higher amounts than IRRIS model. In the period from day 22 to 40 and day 75 to 80 the amounts are some what similar in the models. A sudden drop in NIWR is due to observed un expected rainfall. Become dissimilar amounts among models along the remaining period of the crop cycle IRRIS is the least in NIWR amounts. The peak period of Wheat NIWR is at 109 to135 day at the growing season and it's clear that CAMISM is the higher model in this period. The sudden drop in NIWR of CAMISM model during the last 5 days before fasting date is due to the decrease in the Kc values. The only model exceeds the fasting date in 
NIWR on heavy soil is IRRIS, for medium soil is the CAMISM model. This means that both models irrigate small amounts at closer intervals.
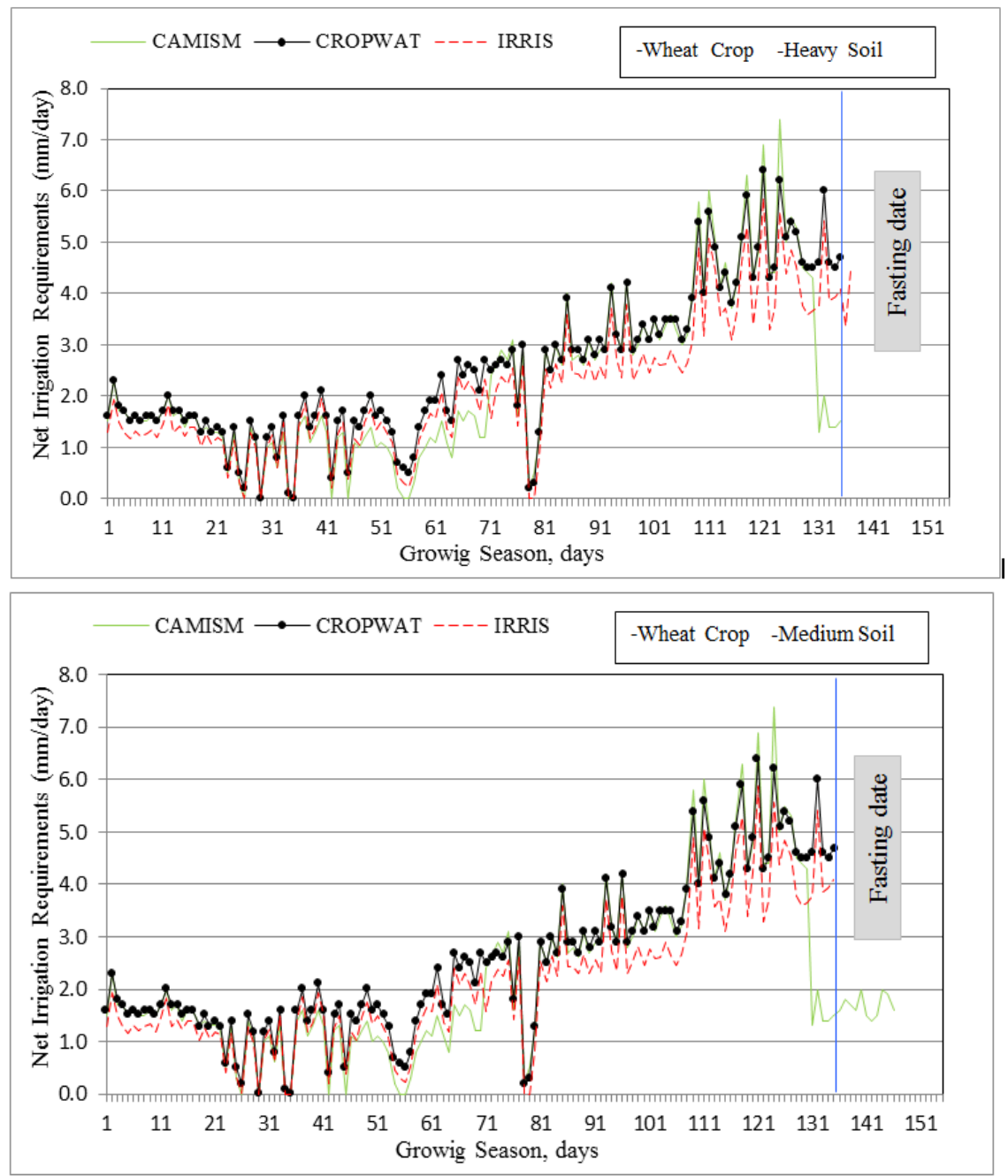

Figure (4): Comparison among the tested models for the net irrigation requirements of Wheat crop in heavy and medium soils.

Table (5): Net irrigation requirements $(\mathrm{mm} / \mathrm{season})$ for Wheat and Corn crops in different soil types.

\begin{tabular}{|c|c|c|c|c|c|}
\hline \multirow[b]{2}{*}{ Season } & \multirow[b]{2}{*}{ Crop } & \multirow[b]{2}{*}{ Soil type } & \multicolumn{3}{|c|}{ Tested models } \\
\hline & & & CROPWAT & CAMISM & IRRIS \\
\hline \multirow[b]{2}{*}{ Winter crop } & \multirow[b]{2}{*}{ Wheat } & $\mathrm{H}$ & 295.2 & 284.7 & 296.4 \\
\hline & & $\mathrm{M}$ & 305.9 & 330 & 288.5 \\
\hline \multirow{2}{*}{ Summer crop } & \multirow{2}{*}{ Corn } & $\mathrm{H}$ & 568.4 & 587.4 & 502.1 \\
\hline & & $\mathrm{M}$ & 561.9 & 600 & 519.8 \\
\hline
\end{tabular}

$* \mathrm{H}=$ Heavy Soil, AWC $=192 \mathrm{~mm} / \mathrm{m} \quad * * \mathrm{M}=$ Medium Soil, AWC $=167 \mathrm{~mm} / \mathrm{m}$. 
The NIWR for Corn crop in the tested models are 568.4, 587.4, and 502.1 $\mathrm{mm}$ on heavy soil. Whereas on medium soil were 561.9, 600, and 519.8 $\mathrm{mm} /$ season respectively. Figure (5) shows that the period from day 1 to 20 differs among the models. Both CROPWAT and CAMISM have higher amounts of NIWR than IRRIS model; however a long the remaining period of the crop cycle the amounts of NIWR are dissimilar in the models and fluctuating. The sudden increase and decrease in NIWR for CAMISM model at the day 54 and 95 owes tothe suddenly increase in the Kc values at the start of mid stage and suddenly decrease at the end of stage as in Figure (5). The sudden increase in NIWR for IRRIS at day 45 due to the variation in climatic parameters which in turn affects ETo value. The differences among curves are clearer in Corn than Wheat.
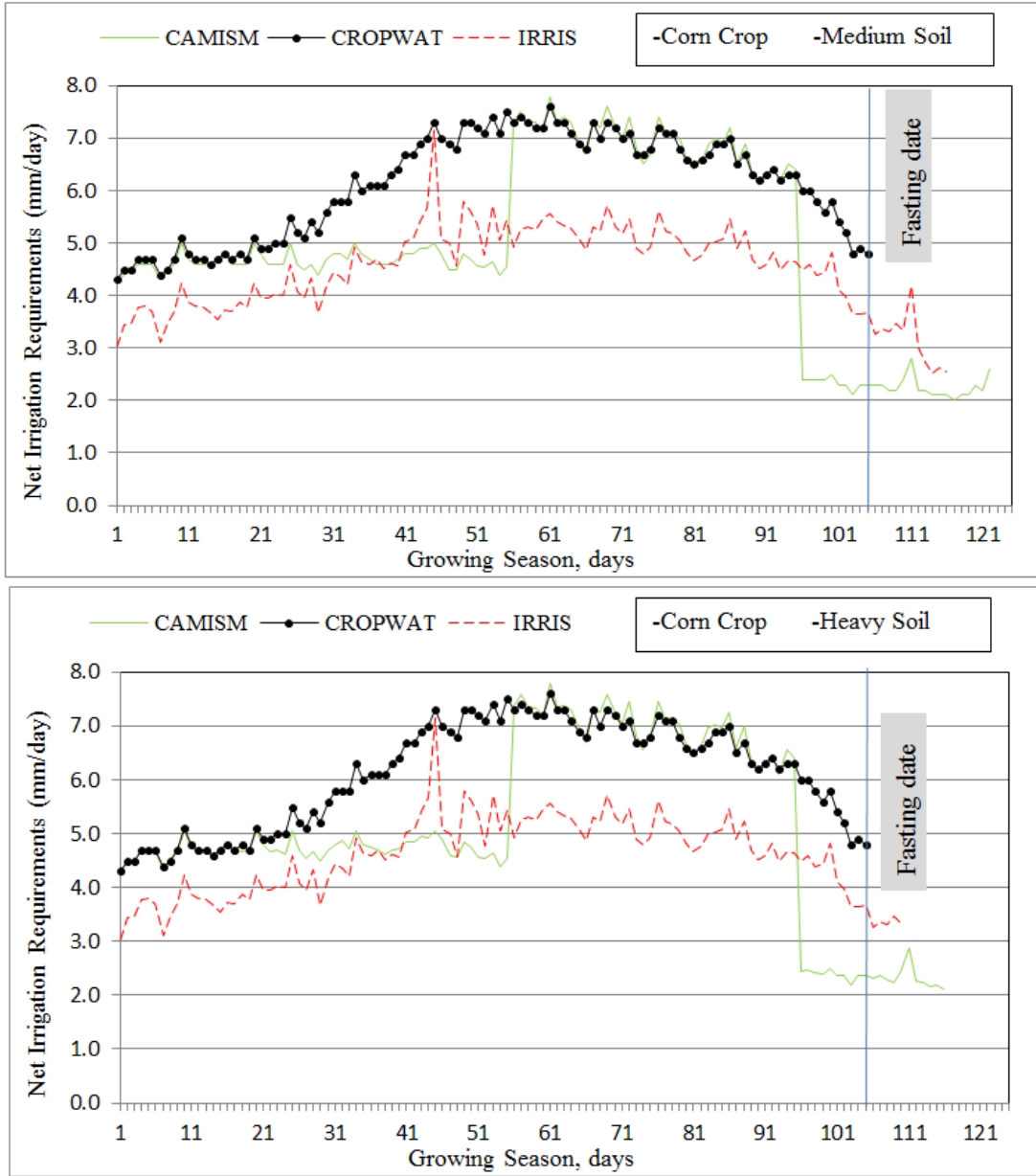

Figure (5): Comparison among the tested models for the net irrigation requirements of Corn crop in heavy and medium soils. 
In summer the temperature raises thus the dropped amounts of solar radiation increases and affects on ETo calculations.CAMISM and IRRIS models exceeds the fasting date as shown in Figure (5), due to the similar reasons mentioned before in Wheat case.

\section{Gross irrigation requirements (GIR)}

Based on the results in Table (6) for Wheat and Corn respectively, the GIR during the whole season of Wheat for heavy soil are 590.4, 505.5, and $592.7 \mathrm{~mm}$ respectively. Which are 611.7, 585.6, and $576.92 \mathrm{~mm}$ on the medium soil. Likewise in case of Corn the GIR during the whole season are 590.4, 505.5, and $592.7 \mathrm{~mm}$ in heavy soil, which are 611.7, 585.6, and $576.92 \mathrm{~mm}$ on medium soil, respectively. The reasons for the decrease in GIR values for IRRIS owes to the equations used for calculating solar radiation. In Table (6) values of GIR generated from CROPWAT for Wheat and Corn are higher than that of CAMISM and IRRIS models. CROPWAT model takes into account the maximum rain infiltration rate (mm/day) unlike CAMISM and IRRIS, furthermore this model considers the amount of daily increase in the plant root depth (Rd) which differ according to the growing stage of crop on the contrary to CAMISM and IRRIS models which use Rd equals to $1 / 3,2 / 3$ and 1 of the effective root depth in initial, mid and crop late stage respectively.

Table (6): Gross irrigation requirements ( $\mathrm{mm} / \mathrm{season})$ for Wheat and Corn crops in different soil types.

\begin{tabular}{|c|c|c|ccc|}
\hline \multirow{2}{*}{ Season } & \multirow{2}{*}{ Crop } & \multirow{2}{*}{ Soil type } & \multicolumn{3}{|c|}{ Tested models } \\
\cline { 4 - 6 } & & \multirow{2}{*}{ CROPWAT } & CAMISM & \multirow{2}{*}{ IRRIS } \\
\hline \multirow{2}{*}{ Winter crop } & \multirow{2}{*}{ Wheat } & $\mathrm{H}$ & 590.4 & 505.5 & 592.7 \\
& & $\mathrm{M}$ & 611.7 & 585.64 & 576.92 \\
\multirow{2}{*}{ Summer crop } & \multirow{2}{*}{ Corn } & $\mathrm{H}$ & 1136.8 & 1041.3 & 1004.1 \\
& & $\mathrm{M}$ & 1123.8 & 1069 & 1039.5 \\
\hline
\end{tabular}

$* \mathrm{H}=$ Heavy Soil, AWC $=192 \mathrm{~mm} / \mathrm{m} * * \mathrm{M}=$ Medium Soil, AWC $=167 \mathrm{~mm} / \mathrm{m}$.

\section{Irrigation scheduling}

The detailed results of irrigation scheduling by the water balance of Wheat and Corn crops at the tested models on heavy and medium soils, respectively are given in Figures (6) through (9).These figures show the daily soil water depletion (Di) for the whole season of Wheat and Corn crops.In the CROPWAT model Di drawn with the daily RAW which increase gradually according to the increase in the root zone depth as shown in the following Figure.In case of CAMISM and IRRIS models three grades of management allowable deficit (MAD) are drawn with the rainfall. Figures (6 and 7) show that the number of irrigations for Wheat 
crop in the heavy soil are 6,7 and 8 for CROPWAT, IRRIS and CAMISM models respectively. The total gross irrigations are 590.4, 592.7 and $505.5 \mathrm{~mm} / \mathrm{season}$ respectively. Whereas in medium soil are 7, 9 and 10 irrigations totaling 611.7, 576.92 and $585.64 \mathrm{~mm} /$ season.

For Corn crop on the heavy and medium soilsare given in Figures ( 8 and 9). The number of irrigations for Corn in the heavy soil is 8,12 and 13 irrigations and the total gross irrigation is 1136.8,1004.1 and 1041.3 $\mathrm{mm}$ /seasonfor CROPWAT, IRRIS, and CAMISM models. Meanwhile, in medium soil are 9, 13 and 15 irrigations totaling1123.8, 1039.5 and 1069 $\mathrm{mm} / \mathrm{season}$. Although the soil type has an effect on the number of irrigations and its GIR amounts among the tested models. The main cause of these differences in the amount of GIR for Wheat and Corn crops is due to the amount of irrigation applied which differs according to the model computation on daily soil moisture depletion.

\section{Deficit irrigation strategy in relation to crop yield}

There is direct relationship between deficit irrigation percentage and yield reduction percentage for Wheat and Corn crops under conditions of water stress. Figures (10) illustrates that the yield reduction for Wheat in heavy and medium soil was 5 to $30 \%$ at water stress 5 to $30 \%$ respectively. Meanwhile the yield reduction for Corn crop in heavy soil is 6.25 to $25 \%$ at water stress 5 to $20 \%$ for three models as given in Figure (11). However, there is reverse relationship between deficit irrigation percentage and actual water use (Eta) ,at $5 \%$ water stress for Wheat; the values of Eta were 349.22, 318.49 and $303.33 \mathrm{~mm}$ for CROPWAT, CAMISM and IRRIS, respectively. Whereas at 30\% were 257.3, 234.7 and $223.5 \mathrm{~mm}$ in heavy and medium soil.

For Corn crop in the heavy soil at 5\% water stress the values of Eta are $609.9,558.13$ and $477.31 \mathrm{~mm}$. while at highest water stress at $20 \%$ were 513.6, 470 and $401.94 \mathrm{~mm}$. But in medium soil at 5\% water stress the values of Eta are 609.9, 533.89 and $494.05 \mathrm{~mm}$ whereas at highest water stress $20 \%$ are 513.6, 449.59 and $416.04 \mathrm{~mm}$. Asin general for the total growing period, the decrease in yield is proportionally less with the increase in water deficit $\left(\mathrm{K}_{\mathrm{y}} \leq 1\right)$ for crops such as Wheat while it is proportionally greater $\left(K_{y}>1\right)$ for crops such as Corn, these results agree with FAO (1979). So, exposure of Corn crop to water stress more than $20 \%$ is avoided unlike Wheat crop. 

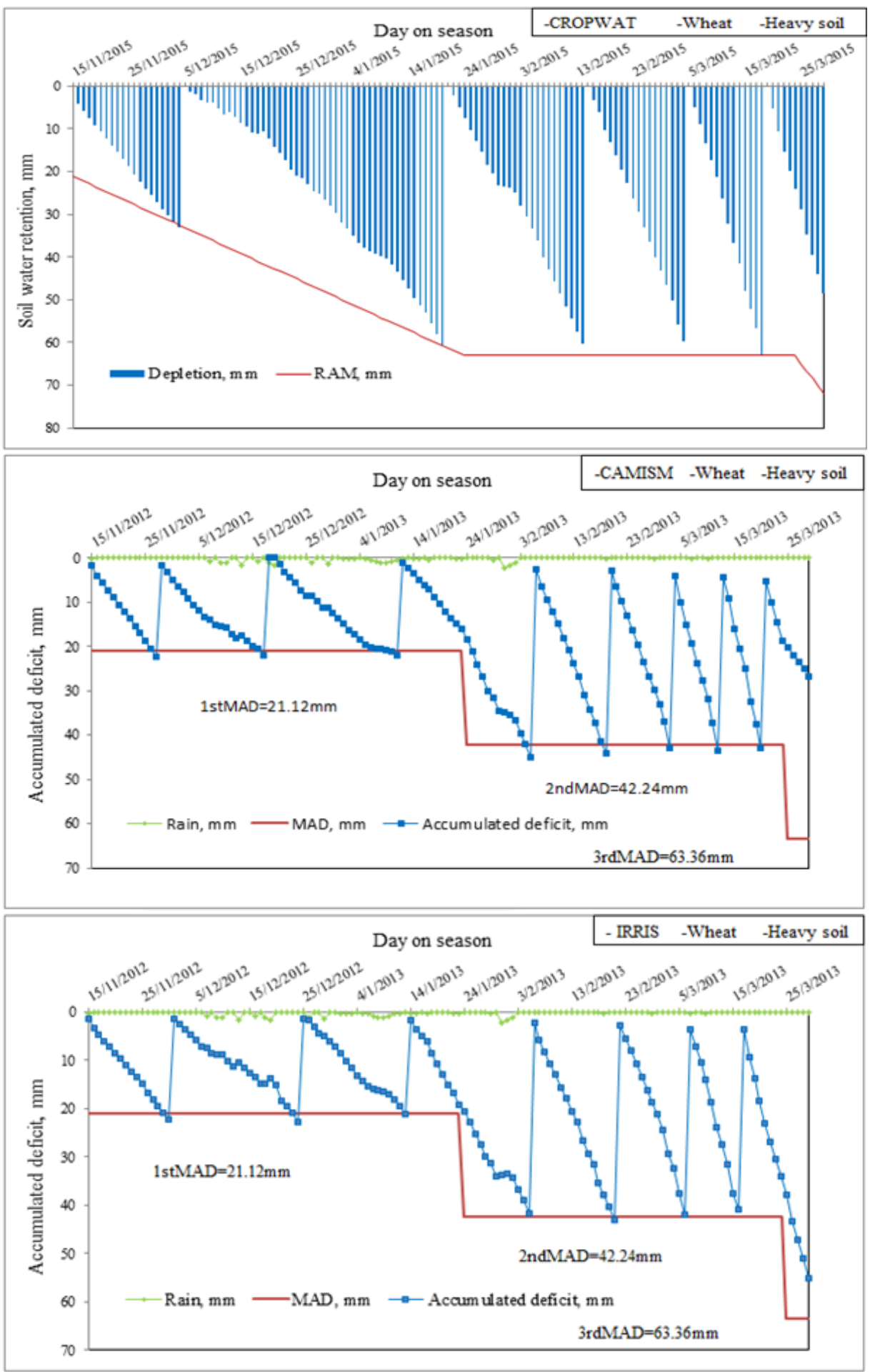

Figure (6): Irrigation scheduling of CROPWAT, CAMISM, and IRRIS models for Wheat in heavy soil.

Misr J. Ag. Eng., April 2015 

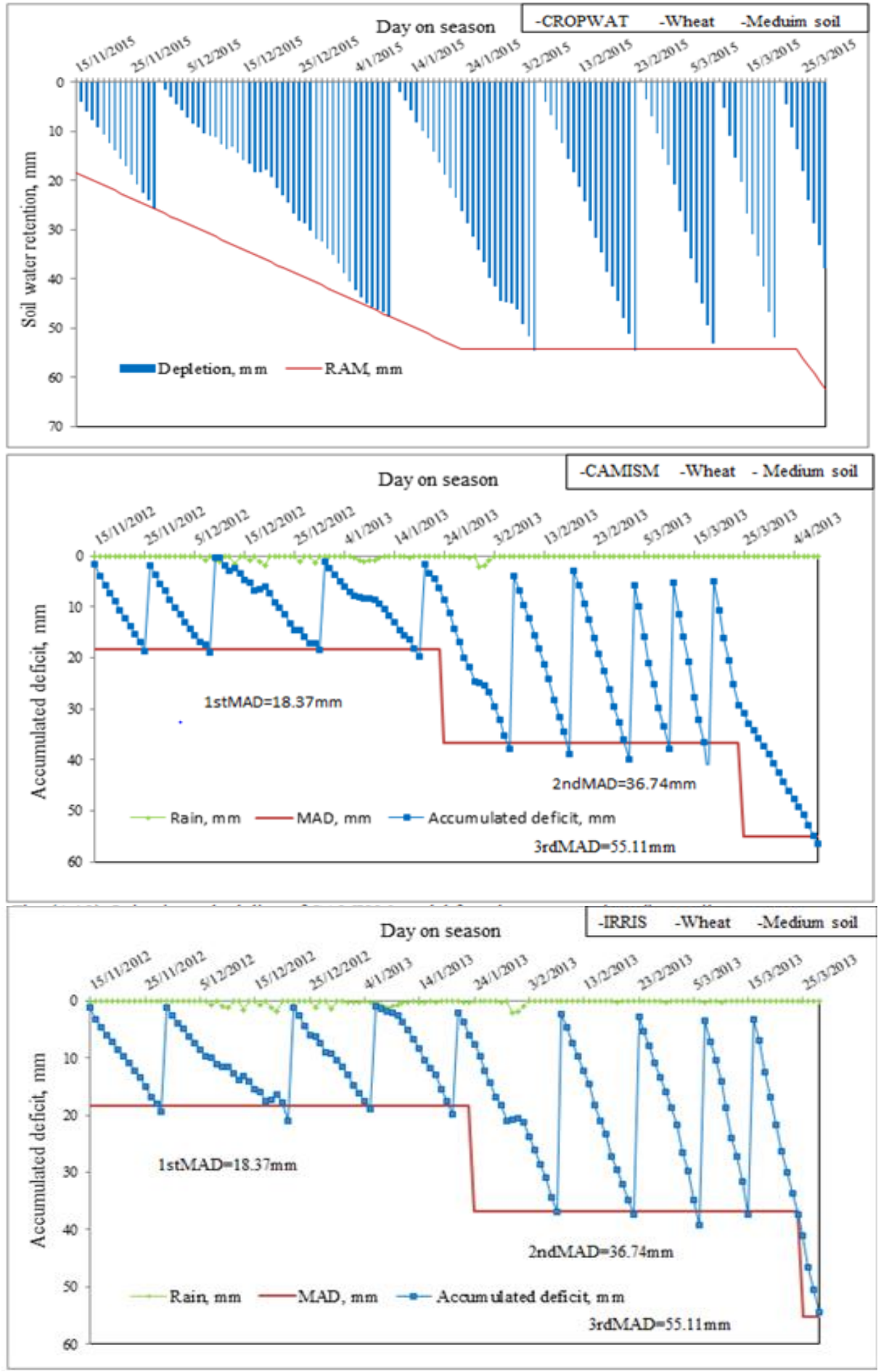

Figure (7): Irrigation scheduling of CROPWAT, CAMISM, and IRRIS models for Wheat in medium soil. 

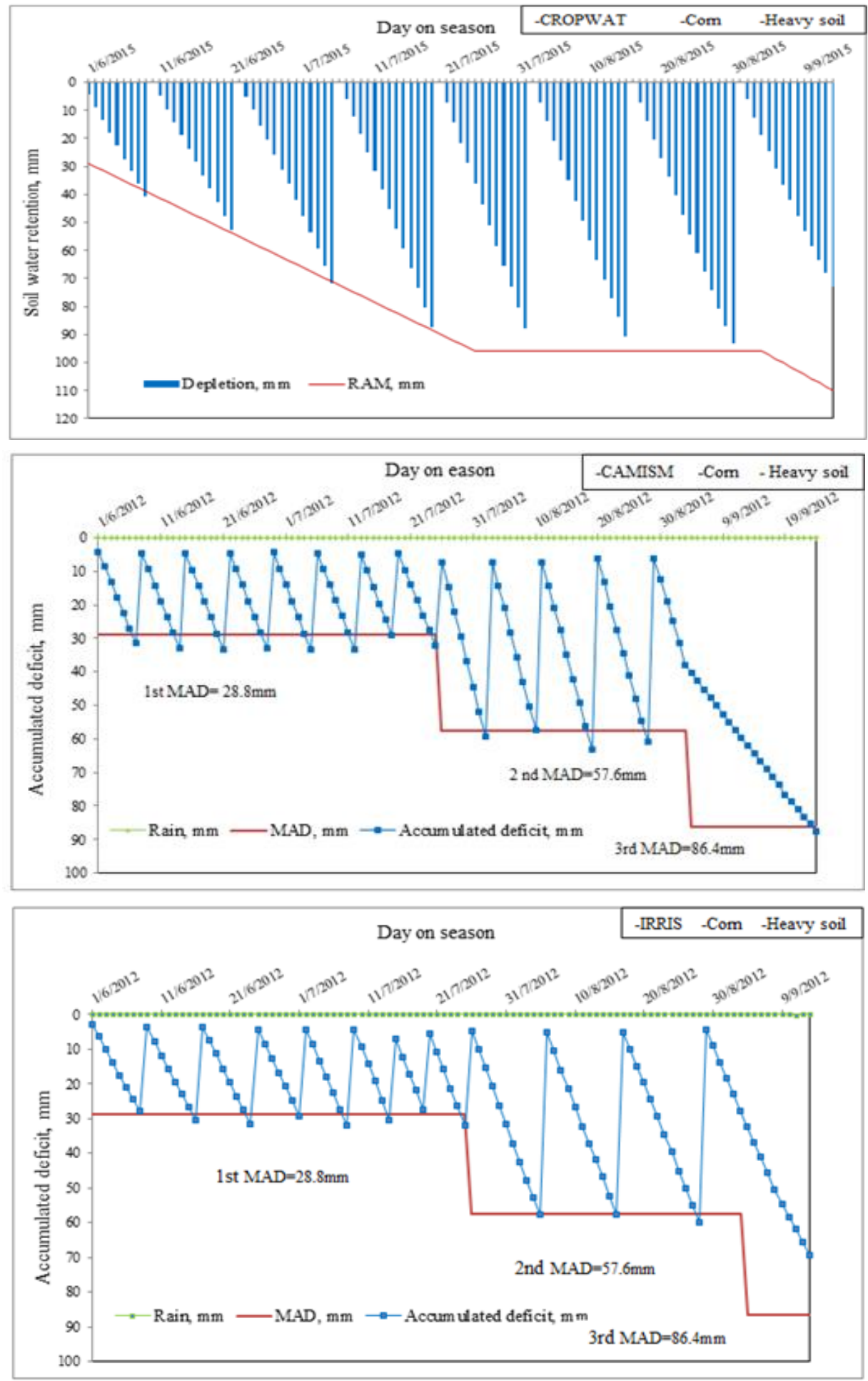

Figure (8): Irrigation scheduling of CROPWAT, CAMISM, and IRRIS models for Corn in heavy soil.

Misr J. Ag. Eng., April 2015 

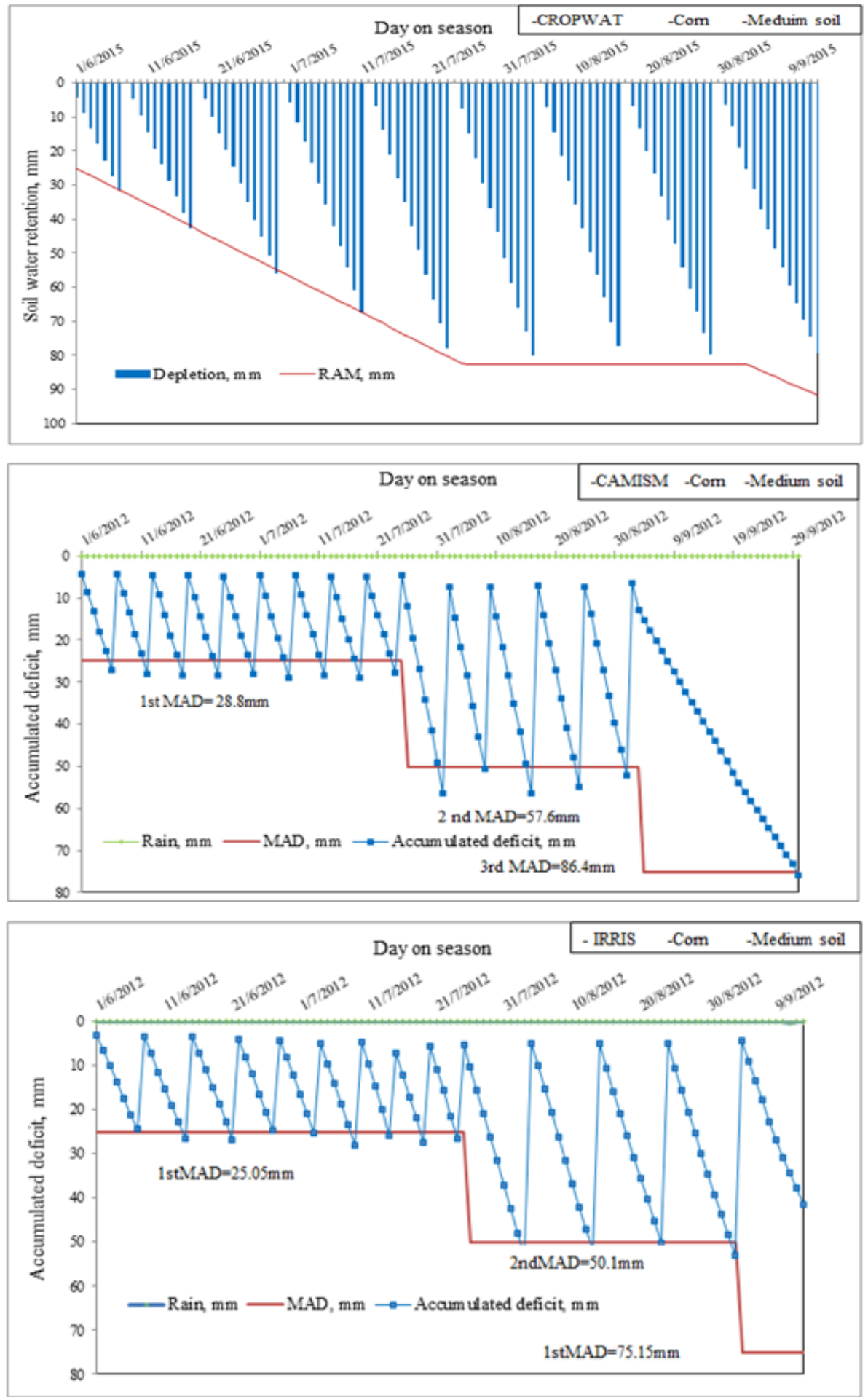

Figure (9): Irrigation scheduling of CROPWAT, CAMISM, and IRRIS models for Corn in medium soil.

Misr J. Ag. Eng., April 2015 


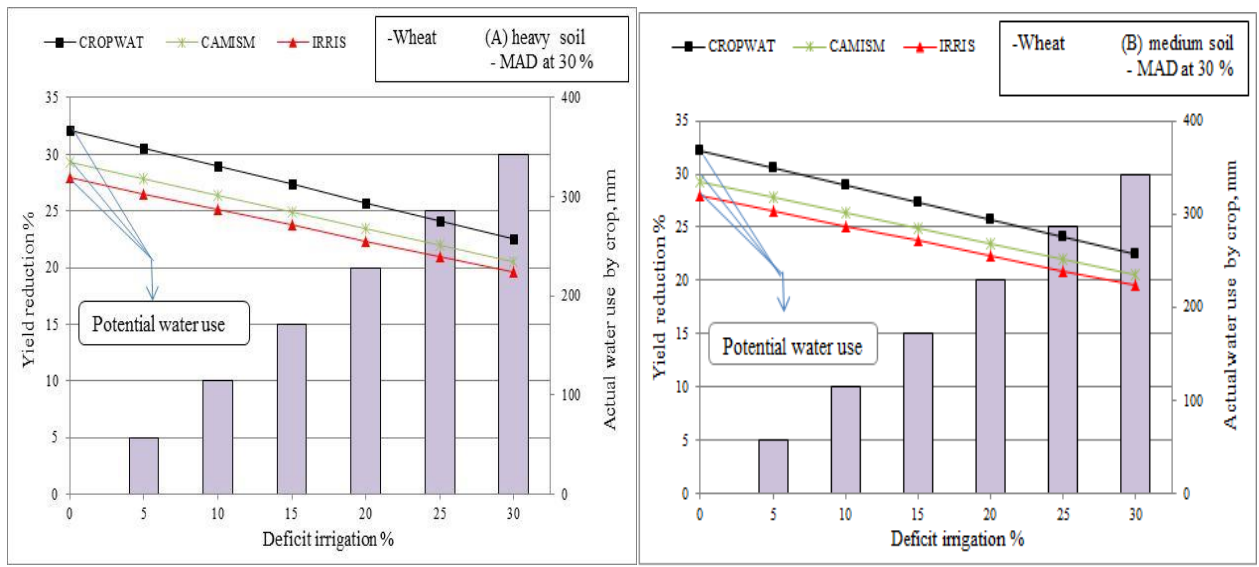

Figure (10): The relationship between percentage deficit irrigation, actual water use and yield reduction for Wheat crop in different soils.
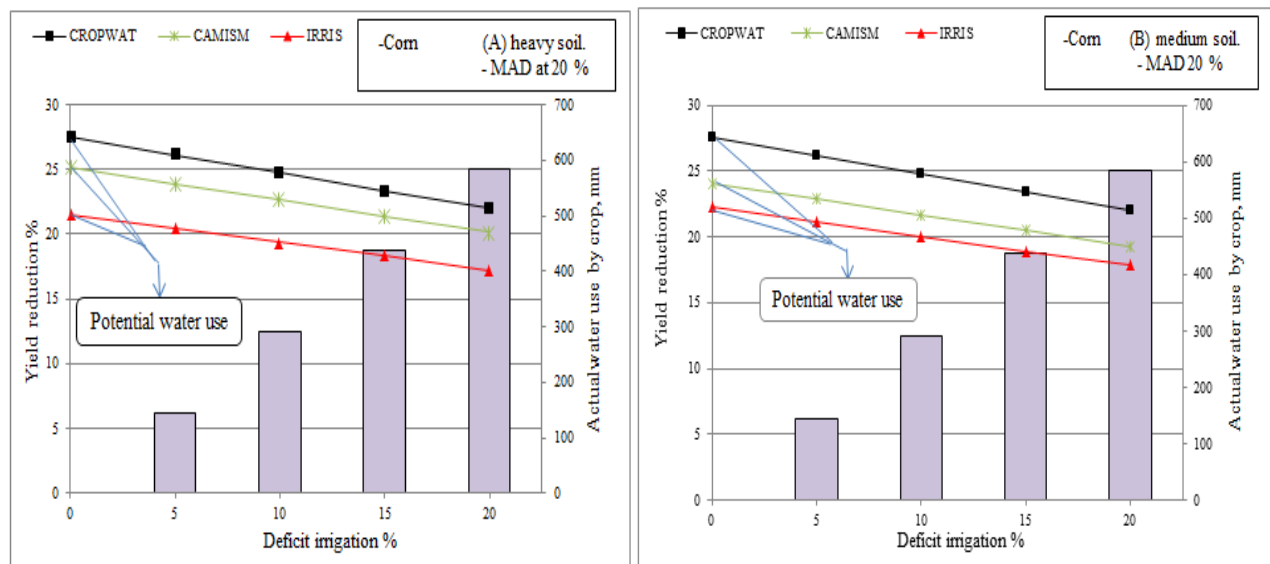

Figure (11): The relationship between percentage deficit irrigation, actual water use and yield reduction for Corn crop in different soils.

\section{CONCLUSIONS}

The following conclusions may be deduced from this study:

1- CAMISM had reliability of the linear relationship with CROPWAT than IRRIS model on calculating ETo.

2- The amount of irrigation water applied by the water balance used modified penman-monteith method in the tested models to schedule the irrigation of Wheat in heavy soil along the growing season was $590.4 \mathrm{~mm}, 505.5 \mathrm{~mm}$ and $592.7 \mathrm{~mm}$ for CROPWAT, CAMISM and IRRIS respectively. And was $611.7 \mathrm{~mm}, 585.64 \mathrm{~mm}$ and $576.92 \mathrm{~mm}$ 
in medium soil. As Corn was $1136.8 \mathrm{~mm}, 1041.3 \mathrm{~mm}$ and 1004.1 $\mathrm{mm}$ in heavy soil and $1123.8 \mathrm{~mm}, 1069 \mathrm{~mm}$ and $1039.5 \mathrm{~mm}$ for medium soil. The number of irrigations added through out the growing season of the Wheat crop was 6, 8 and 7 irrigations and were 7, 10 and 9 irrigations for heavy and medium soil respectively. However, corn in heavy soil 8, 13 and 12 irrigations, and in medium soil was 9, 15 and 13 irrigations.

3- There is adirect relationship between deficit irrigation $\%$ and yield reduction $\%$ for Wheat and Corn crops under conditions of water stress uniformly spread over the whole crop cycle in the tested models. Meanwhile, there is reverse relationship between deficit irrigation $\%$ and actual water use.

\section{REFERENCES}

Allen, R.G., L.S. Pereira, D. Raes, and M. Smith.(1998). Crop evapotranspiration guidelines for computing crop water requirements.Irrigation and Drainage Paper 56, FAO, Rome, 300 P.

Barrett, J. W. H. and G. V. Skogerboe.(1980). Crop production functions and the allocation and use of irrigation water.Agr. Water Management 3: 53-64.

Clark, G. A., D. Rogers, M. Alam, D. Fjell, and S. Briggeman(2002). A mobile irrigation lab for water conservation: I. Physical and electronic tools.Conference Proceedings, Irrigation Association International Irrigation Technical Conference. Falls Church, Va.: Irrigation Assoc, 5p.

FAO.(1979). Yield response to water by J. Doorenbos\& A.H. Kassam. Irrigation and Drainage Paper No. 33. FAO, Rome, PP 6-13.

FAO.(1986). Yield response to water by J. Doorenbos\& A.H. Kassam. Irrigation and Drainage Paper No. 33. FAO, Rome, Italy.1-13P.

FAO.(1992). CROPWAT: A computer program for irrigation planning and management. Developed by: Martin Smith.FAO Irrigation and Drainage Paper 46.Rome, Italy, 1-123P. 
FAO.(1998).Crop evapotranspiration :Guidelines for computing crop water requirements. By: Richerd Allen, Luis Pereira, Dirk Raes and Martin Smith. FAO Irrigation and Drainage paper 56.Rome, Italy, $300 \mathrm{P}$.

Hillel, D. (1972). The relationship between field water balance and water use efficiency. In Optimizing the Soil Physical Environment Toward Greater Crop Yields, Ed. D. Hillel, PP 79-100. New York: Academic Press.

Henggeler, J. (2002).Software programs currently available for irrigation scheduling (Kansched).Conference Proceedings, Irrigation Association International Irrigation Technical Conference. Falls Church, Va: Irrigation Assn.PP120-129.

Joern, B. and P. Hess.(1997).Irris scheduler help contents.Agronomy department, Purdue University, USA, PP1-13.

Keller, J. and R. D. Bliesner.(1990). Sprinkler and trickle irrigation. An Avi book, Van Nostrand Reinhold, New York, 652 P.

Laghari, K. Q. (2009). Perceptive Research on Irrigation Scheduling And Water Management. Mehran University of Engineering TechnologyJamshoro, PP 1-135.

Ramadan, M.H., M.A. El-Adl, H.N. Abd El-Mageed and M. Maher.(2006).Computer-Aided Mapping Irrigation Scheduling for Arab Republic of Egypt.The 2nd International Conf. on Water Resources \& Arid Environment (2006), 22P.

SAS (2011).Version 9.3. SAS institute inc, Cary, NC, USA.

Savva,A. P. and K. Frenken.(2002).Crop water requirements and irrigation scheduling.Irrigation manual. Module 4, FAO SubRegional Office for East and Southern Africa, PP1-121.

Smajstrla, A.G., B.J. Boman, D.Z. Haman, F.T. Izuno, D.J. Pitts, and F.S. Zazueta.(2006). Design of Agricultural Irrigation Systems in Florida. BUL249, one of a series of the Agricultural and Biological Engineering Department, Florida Cooperative Extension Service, Institute of Food and Agricultural Sciences, University of 
Florida.Original

February1997.ReviewedFebruary2006.Availableat:http://edis.ifas.uf 1.edu. Accessed on 3May.2013.15P

Smith, M. (1992).CROPWAT - A computer program for irrigation planning and management, Irrigation and Drainage Pap.46, Food and Agric. Org. of the U. N., Rome.PP 1-75.

Stewart, B.A. and J.T. Musick, (1982).Conjunctive use of irrigation and rainfall in semi-arid regions. Advances in Agronomy 1: 1-23.

Van Heerden, P., C.T. Crosby, and C.P. Crosby (2001). Using SAPWAT to estimating water requirement of crops in selected irrigation areas managed by the Orange-Vaal and Orange-Reit Water User Associations. WRC Report No TT 163/01, (2001). ASABE Standards.S526.3 SEP20077: Soil and waterterminology. St. Joseph, Mich.: ASABE.PP 1273-1279.

Woyessa, Y.E., E. Pretorius and P. van Heerden(2004). The Application of SAPWAT model in irrigation water management planning for the sand -vet irrigation scheme : contribution towards an integrated catchment management system.Proceedings of the 2004 Water Institute of Southern Africa (WISA) Biennial Conference, 2-6 May 2004 ISBN: 1-920-01728-3.

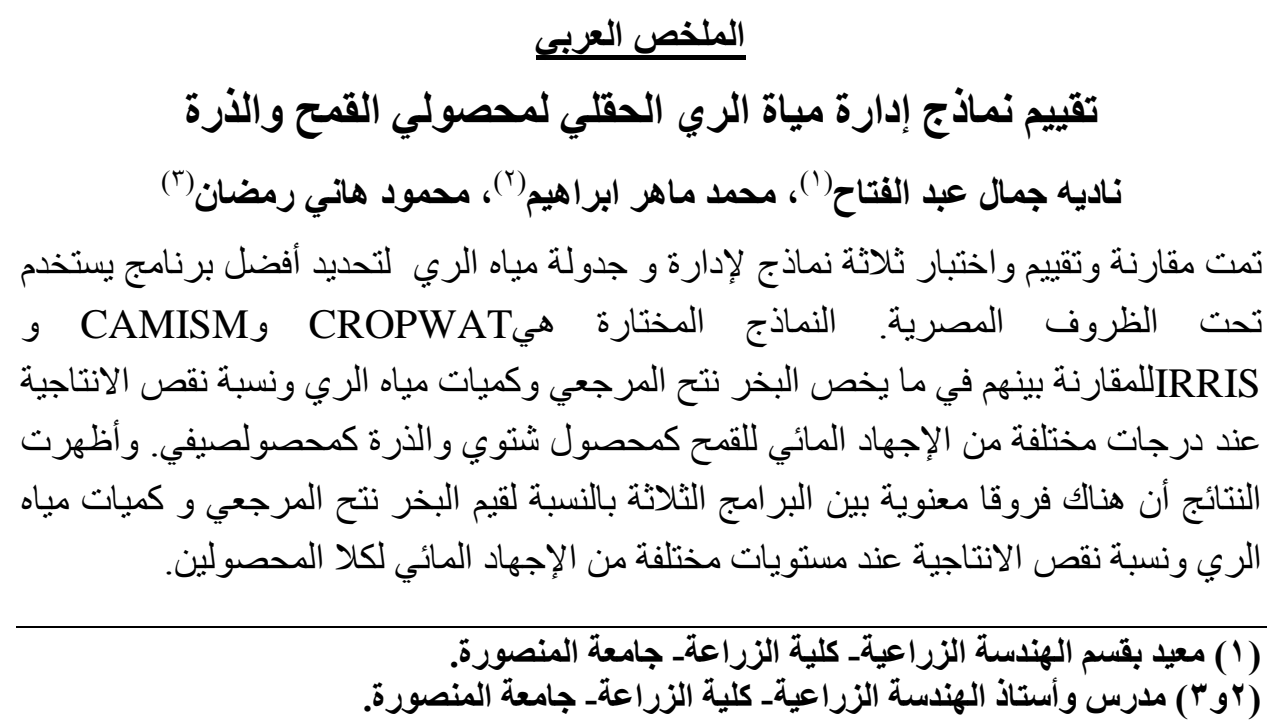




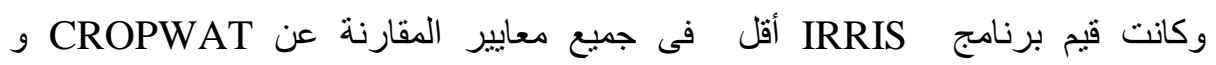
CAMISM أما بالنسبة لجدولة مياة الري للمحصولين في الثثلاثة بر امج فكان العمق الكلى لمياه

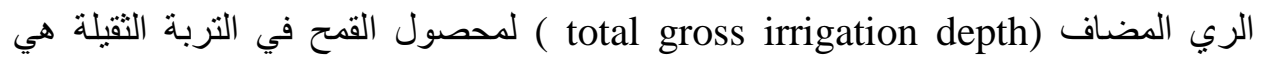

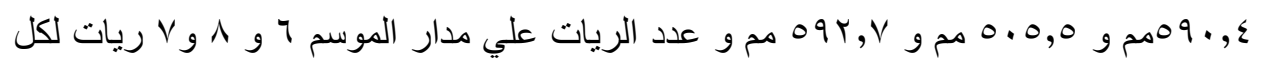
من CROPWAT و CAMISM و IRRIS علي التوالي وأما في التربة المتوسطة فكانت

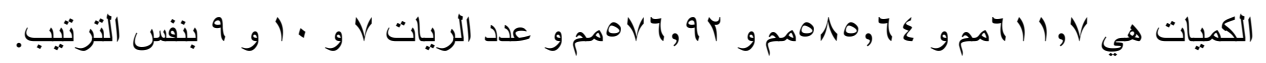

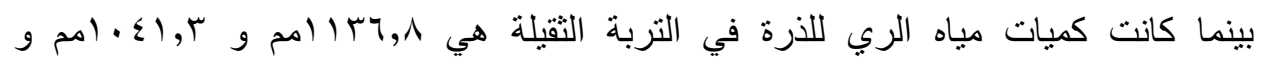

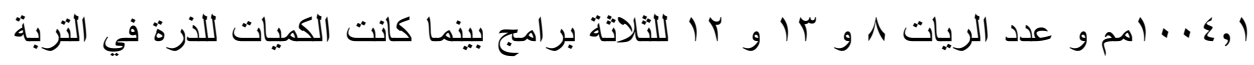

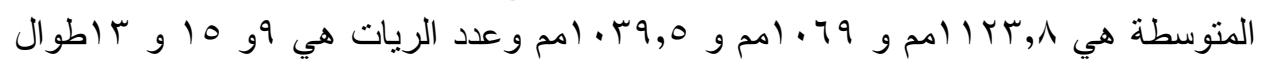

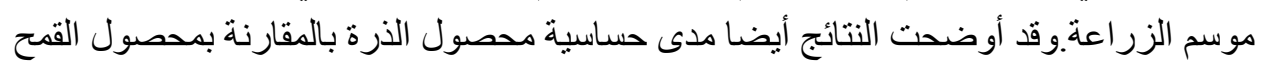

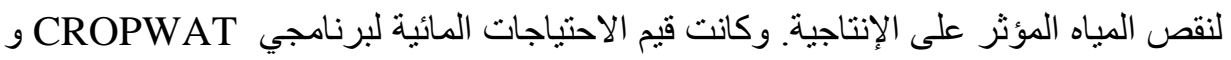

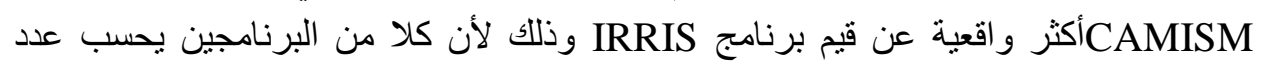

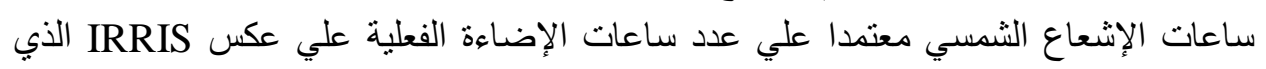

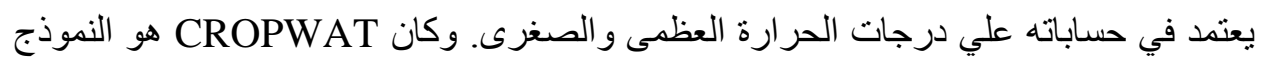
الوحيد بينهم الذي يتيح للمستخدم حساب النقص في كمية مياة الري و علاقتة بإنتاجية المحصول. 